\title{
Geochemical and Petrographic Interpretation of Sandhan Formation: An Insight into Provenance, Tectonics and Paleoclimatic Conditions
}

\author{
Shubhendu Shekhar, Avinash Shukla and Pramod Kumar \\ Department of Geology, Center for Advanced Studies \\ University of Delhi, Delhi 110007, India \\ Email: shekhar.shubhendu@gmail.com
}

\begin{abstract}
The relative sea-level fall in terminal Cenozoic exposed continental shelf of Kutch provided opportunity to develop a fluvial system of braided nature. The terminal Cenozoic formation of Kutch, the Sandhan Formation provides a rare opportunity where a clear transition from a marine to fluvial succession can be identified in the field. The occurrence of fluvial deposits in the rock record suggest an abrupt and considerable fall in the base level. The $\sim 157 \mathrm{~m}$ thick upper part of the Sandhan Formation is deposited in the fluvial environment. The fluvial succession of the Sandhan Formation has not been studied for their sediment geochemistry. Provenance, tectonic setting, paleo-weathering, and paleoclimate of the upper part of the Sandhan Formation is interpreted on the basis of extensive geochemical and petrographic analysis of sandstone samples by using XRF, the bivariate diagram Log $\left(\mathrm{SiO}_{2} / \mathrm{Al}_{2} \mathrm{O}_{3}\right)$ versus $\mathrm{Log}\left(\mathrm{Na}_{2} \mathrm{O} / \mathrm{K}_{2} \mathrm{O}\right)$ diagram, QFL diagram, Provenance Discrimination Plot, $\mathrm{SiO}_{2} / \mathrm{Al}_{2} \mathrm{O}_{3}$ ratio with $\mathrm{K}_{2} \mathrm{O} / \mathrm{Na} 2 \mathrm{O}$ ratio, Chemical Index of Alteration (CIA) weathering indices, Plagioclase Index of Alteration (PIA), Chemical index of Weathering (CIW), A-CN-K Diagram, $\mathrm{SiO}_{2} / \mathrm{Al}_{2} \mathrm{O}_{3}$ ratio and binary $\mathrm{SiO}_{2}$ wt. $\%$ versus $\left(\mathrm{Al}_{2} \mathrm{O}_{3}+\mathrm{K}_{2} \mathrm{O}+\mathrm{Na}_{2} \mathrm{O}\right)$ wt. $\%$ diagram. These provided the detailed geological origin of the upper part of the Sandhan Formation as, it originated from a mixed provenance (quartzose sedimentary and mafic igneous), with arkose to subarkose nature. The upper part of Sandhan Formation is formed in an arid paleoclimate, both Active Continental Margin (ACM) and Passive Margin (PM) tectonic setting and moderate to intense paleo-weathering conditions.
\end{abstract}

Keywords: Sandhan Formation, Kutch, Siliciclastic Rocks, Sediment Geochemistry, Clastic Provenance, Tectonic Setting, Paleo-weathering, Paleoclimate

\section{INTRODUCTION}

The term Provenance is coined from the Latin term Provenire, meaning to originate. The provenance analysis comprises all investigation that results in the reconstruction of the lithospheric history (Basu, 1985). Provenance analysis is aimed at reconstructing the parentrock assemblages of sediments and climatic physiographic condition of the source area from which sediment is derived. The final objective of provenance study is to infer the characteristics of the source areas from the measurement of compositional and textural properties of sediments (Pettijohn et al., 1987). Geology of the provenance area from which the sediments are derived and the climates through which sediments have undergone before burial, have a major influence on the composition of fluvial detritus. Fluvial deposits are a sensitive indicator of tectonic 
processes and also carry a subtle signature of the climate at the time of deposition (Miall, 1977). The chemical and mineralogical compositions of clastic sedimentary rocks are controlled by various factors including source rock composition, weathering, erosion, transportation, and sedimentation processes. Complete information about the composition of source rock, tectonic setting of basin and evolution of crust are present in the Sedimentary rocks (Taylor and McLennan, 1985; Gibbs et al., 1986; Condie, 1993; McLennan et al., 1995). The study of sedimentary clastic rocks remained focused on facies modeling and detrital mode estimation (Pettijohn et al., 1987). The standard petrographical method has remained; the analysis of the polycrystallinity of quartz grains (Basu et al., 1975), rock fragments and types of feldspar (Pettijohn et al., 1987), estimation of relative proportion of quartz, feldspar and rock fragments to interpret tectonic setting (Dickinson, 1985), and examination of roundness of grain, textural and mineralogical maturity to infer transport history (Pettijohn et al., 1987). For the identification of source rock, grain roundness and an average degree of feldspar alteration and climate of the source area (Folk, 1980). The geochemical studies of clastic sedimentary rocks of all the geological ages were initiated by Wildmen and Condie (1973), Nance and Taylor (1977), Taylor et al. (1983), Taylor and McLennan (1985). The geochemical composition of clastic rock has been extensively used to recognize the composition of source area (Wronkiewicz and Condie,1987, 1990; Naqvi et al., 1988, 2002; McLennan et al., 1995; Cullers, 2000; Cullers and Podkovyrov, 2000; Condie et al., 2001), to evaluate weathering processes and paleoclimate (Nesbitt and Young, 1982; Sreenivas and Srinivasan, 1994; Fedo et al.,1995, 1996), to reconstruct the tectonic setting of depositional basin (Bhatia, 1983; Bhatia and Crook, 1986; Roser and Korsch, 1986, 1988; McLennan et al., 1990).

Recent advancement is to integrate the petrography of clastic rocks with their geochemical data, in order to get more accurate information about their provenances, paleoclimate and the tectonic processes (McLennan et al., 1993; Zimmerman and Bahlburg, 2003). Climate and topography in the source region also control the vegetation, which plays an important role as a principal modulator of the output from the source area into first-order tributaries (Weltje et al., 1998). Numerous studies have been carried out to infer the genesis of the siliciclastic sediments (Dickenson et al., 1983; Nesbitt and Young, 1982, 1984; Bhatia, 1983; Roser and Korsch, 1988; McCann, 1991; Condie et al., 1992) and identification of palaeotectonic settings of provenances based on geochemical analysis of siliciclastic rocks (Dickinson and Suczek, 1979; Bhatia, 1983; Bhatia and Crook, 1986; Roser and Korsch, 1986; McLennan and Taylor, 1991).

The approach in the area of provenance study shifted towards the geochemical characterization, because of rapid acquisition of a large number of variables precision and high applicability to both coarse-grained and fine-grained sediments. Several major, trace, REE based discrimination diagram are proposed to decipher the source rock provenance of siliciclastic sediments (McLennan et al., 1983; Taylor and McLennan, 1985; Condie, 1993). Bhatia (1983) observed a decrease in $\mathrm{Fe}_{2} \mathrm{O}_{3}+\mathrm{MgO}, \mathrm{TiO}_{2}, \mathrm{Al}_{2} \mathrm{O}_{3} / \mathrm{SiO}_{2}$ and increase in $\mathrm{K} 2 \mathrm{O} /$ $\mathrm{Na}_{2} \mathrm{O}, \mathrm{Al}_{2} \mathrm{O}_{3} /\left(\mathrm{CaO}+\mathrm{Na}_{2} \mathrm{O}\right)$ in sandstone suit from oceanic island arc to continental island arc to active continental margin to passive continental margin. Bhatia (1983) also observed the ratio of $\mathrm{SiO}_{2} / \mathrm{Al}_{2} \mathrm{O}_{3} \& \mathrm{~K}_{2} \mathrm{O} / \mathrm{Na}_{2} \mathrm{O}$ increased with the sandstone and mudstone maturity (Fatima and Khan, 2012). Roser and Korsch (1986) determined the provenance and tectonic setting using $\mathrm{SiO}_{2} \& \mathrm{~K}_{2} \mathrm{O} / \mathrm{Na}_{2} \mathrm{O}$ ratio. Bhatia and Crook (1986) noted an increase in REE abundance and decrease in Eu anomaly as sandstone become more mature. The geochemical composition of the siliciclastic sediments can also be used as a sensitive indicator of the intensity of chemical weathering, paleoclimate condition. Chemical index of alteration (CIA), $\mathrm{SiO}_{2}-\mathrm{Al}_{2} \mathrm{O}_{3}+\mathrm{K}_{2} \mathrm{O}+\mathrm{Na}_{2} \mathrm{O}$ diagram, index of compositional variability, $\mathrm{A}-\mathrm{CN}-\mathrm{K}\left(\mathrm{Al}_{2} \mathrm{O}_{3}-\mathrm{CaO}+\mathrm{Na}_{2} \mathrm{O}-\mathrm{K}_{2} \mathrm{O}\right)$ plots are the geochemical parameter to infer the paleoclimate condition, maturity, and intensity of weathering (Nesbit and Young, 1984; Fatima and Khan, 2012). The detrital composition of sandstone is controlled by several factors. Studies have revealed that their mineralogy is influenced by 
tectonic setting (Dickinson and Suezek, 1979; Ingersoll and Suezek, 1979 and Dickinson, 1985).

The aim of this paper is to interpret the provenance, tectonic setting, paleoweathering and paleoclimatic conditions during sedimentation of the upper part of the Sandhan Formation on the basis of extensive geochemical and petrographic analysis.

\section{GEOLOGICAL SETTING}

The Kutch basin is structurally controlled peri-cratonic rift basin developed at the western margin of India (Biswas, 1992). During Cenozoic, the Kutch basin evolved as a passive margin sag-basin, exposed along the western margin of Kutch (Fig.1). Only after Deccan volcanism, the sedimentation in Kutch basin initiated, which is exposed along narrow coastal plain trending NNW-SSE separated by the various magnitude of unconformity, non-conformity or paraconformity (Biswas, 1992).

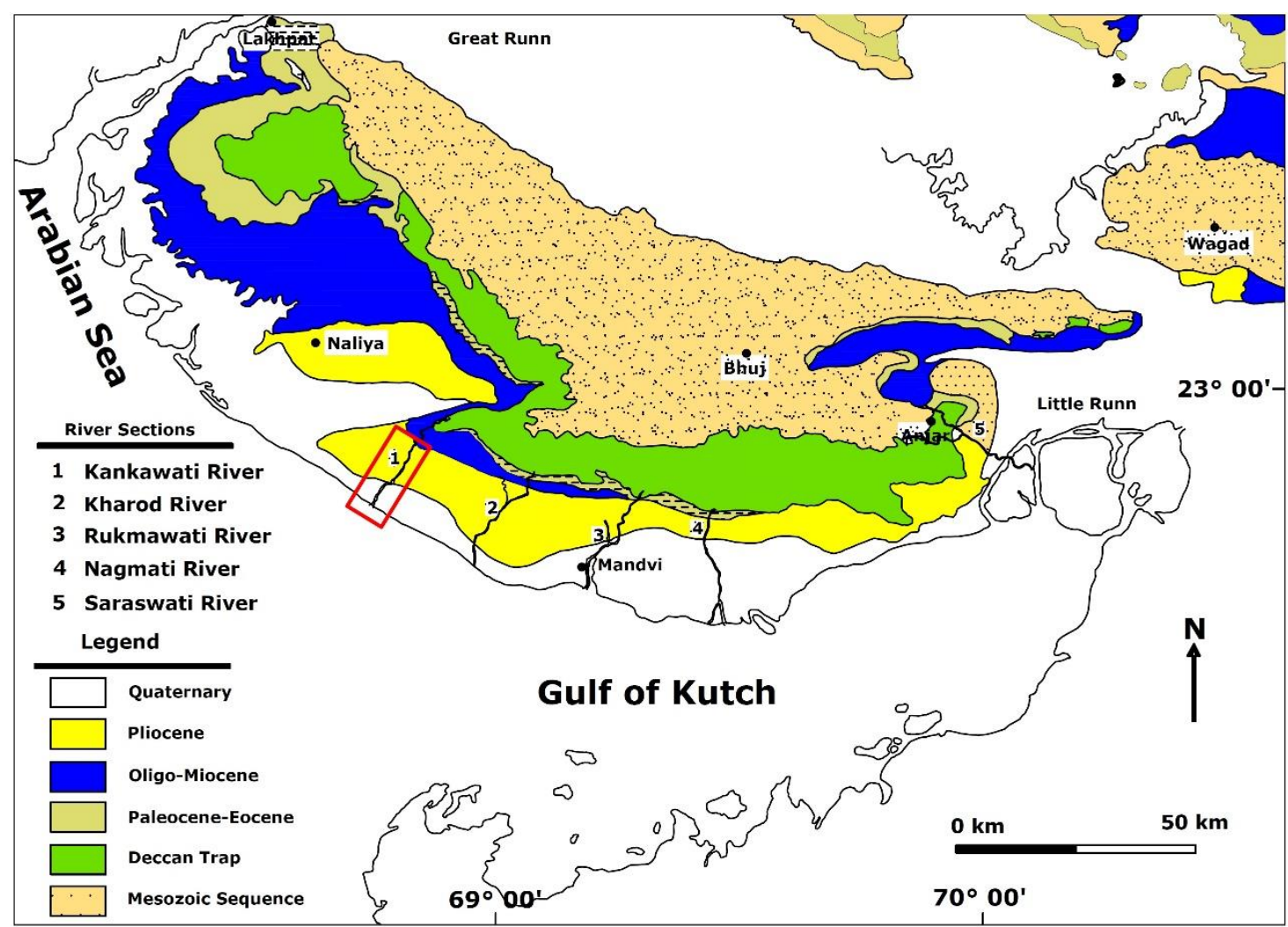

Fig. 1: Geological map of the Kutch basin, the red rectangular area is showing the studied, Kankawati river section (after Biswas and Deshpande, 1970).

The terminal Cenozoic formation of Kutch is labeled as Sandhan Formation. It is siliciclastic dominated (Fig. 2). The age of the Sandhan Formation is not clear because of the absence of age-diagnostic fauna, so, the Pliocene age is assigned to it because of a prominent break in sedimentation above Lower-Middle Miocene and order of superposition (Biswas, 1992). Nearly 292m thick Sandhan Formation is exposed along cliffs and banks of Kankawati River as continuous outcrops with several exposure gaps towards upper part. The lower unconformity above Chhasra Formation is characterized by a conglomerate bed and upper contact with Subrecent sediments is identified by regional and laterally persistent paleosol horizon. The $\sim 157 \mathrm{~m}$ thick upper part of the Sandhan Formation is deposited in the fluvial environment is fluvial 
succession of the Sandhan Formation is deposited due to sudden fall in sea-level in force regressive setting (Shekhar et al., 2018). According to Biswas (1992), the depositional environment of Sandhan Formation is interpreted to be supra littoral to deltaic or foreshore.
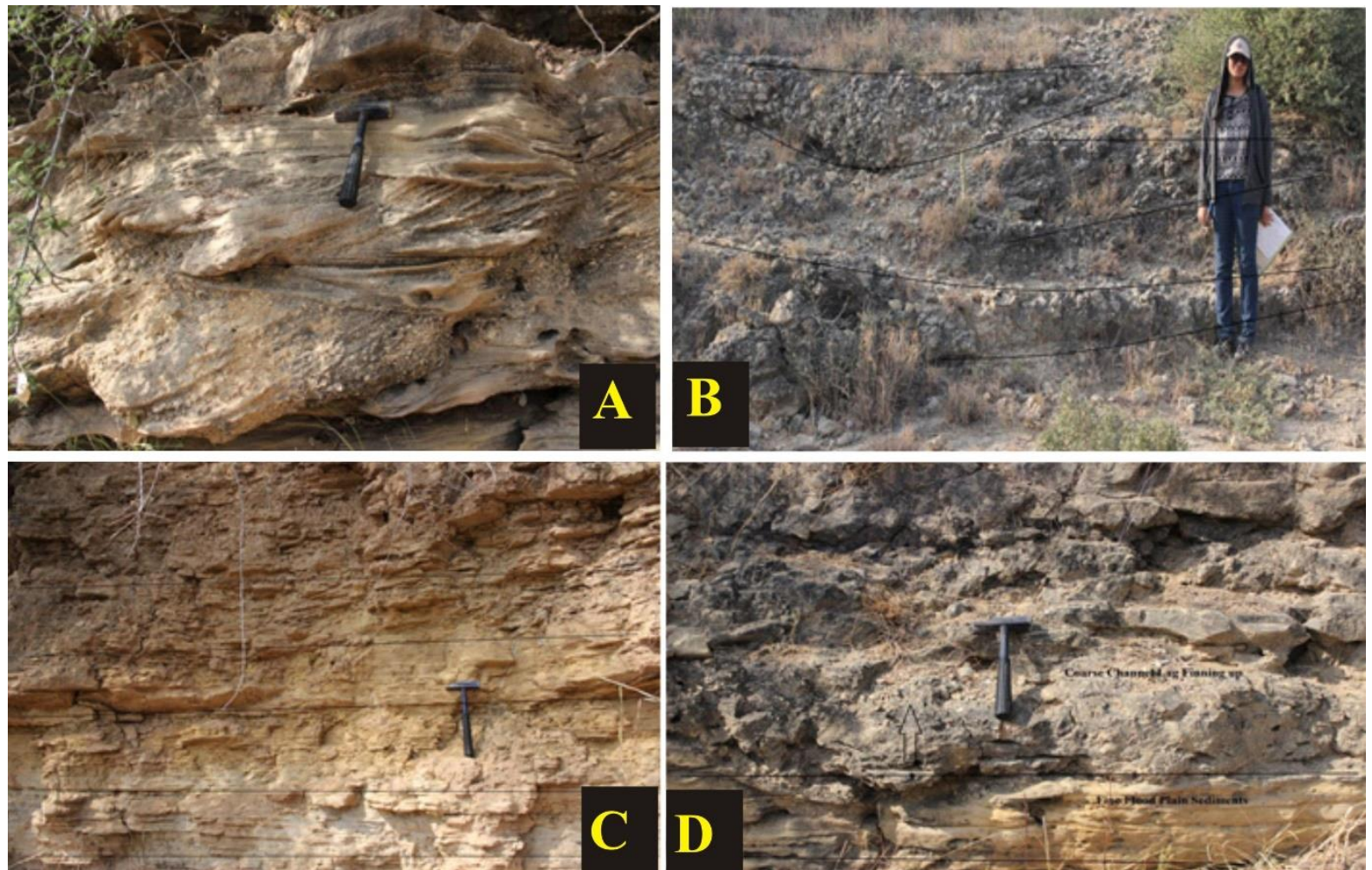

Fig. 2: Outcrop photographs of the upper part of the Sandhan Formation i.e. fluvial facies identified in the field (Facies code according to Miall, 1977). (A.) Trough cross stratified gravel forming gravel bar (Gt). (B.) Sediment gravity flow showing an elongated lobe geometry (Gmm). (C.) Inter-laminated mud, sit and sandstone (FI). (D.) Floodplain sediment (Fsm) above channel characterized by mud, silt, (Shekhar et al., 2018).

\section{METHODOLOGY}

The type section of the Sandhan Formation along the Kankawati river section was chosen for detailed studies. Detailed field works were carried out. The lithological boundary between the marine and fluvial succession was identified in the field. Lower and Upper boundary of the fluvial succession were demarcated in the field. A sedimentary log was prepared on the basis of the thicknesses of the individual beds measured and lithological variation observed during the field work. Facies analysis was carried out on the upper part of the Sandhan Formation. Identified facies based on their sedimentary structures, grain size, type of contact, were grouped into facies association. Samples were collected from all the facies to prepare thin sections for petrographic observation and for the geochemical analysis work. The samples representing different facies were used to prepare thin section applying standard procedure. The framework constituents of the thin sections were counted randomly with grid spacing adjusted such that to allow 300-grain counts, without counting a grain more than once. In all cases, the effects of diagenesis were removed so that the original detrital composition could be accurately determined (Rumelhart and Ingersoll, 1997). The average modal composition is evaluated based on the grain counting. 


\section{RESULTS}

\section{Geochemistry of Sandstone:}

Ten major element oxides $\left(\mathrm{SiO}_{2}, \mathrm{TiO}_{2}, \mathrm{Al}_{2} \mathrm{O}_{3}, \mathrm{FeO}, \mathrm{MnO}, \mathrm{MgO}, \mathrm{CaO}, \mathrm{Na}_{2} \mathrm{O}, \mathrm{K} 2 \mathrm{O}\right.$, and $\mathrm{P}_{2} \mathrm{O}_{5}$ ) and 12 trace elements $(\mathrm{Cu}, \mathrm{Cr}, \mathrm{Ba}, \mathrm{Nb}, \mathrm{Rb}, \mathrm{Sr}, \mathrm{Sc}, \mathrm{Ni}, \mathrm{Zn}, \mathrm{Zr}, \mathrm{V}$, and $\mathrm{Y}$ ) were analyzed by XRF on pressed powdered pellets (Table-1). Major elements data is analyzed in oxide percentage and the trace elements are in parts per million (ppm).

\section{Geochemical Classification of Sandstone}

Sandstone of the present study was classified according to the scheme proposed by Pettijohn et al., 1972. In the bivariate diagram $\log \left(\mathrm{SiO}_{2} / \mathrm{Al}_{2} \mathrm{O}_{3}\right)$ versus $\mathrm{Log}\left(\mathrm{Na}_{2} \mathrm{O} / \mathrm{K}_{2} \mathrm{O}\right)$ diagram sandstone is plotted in the field of arkoses to subarkose (Fig. 3).

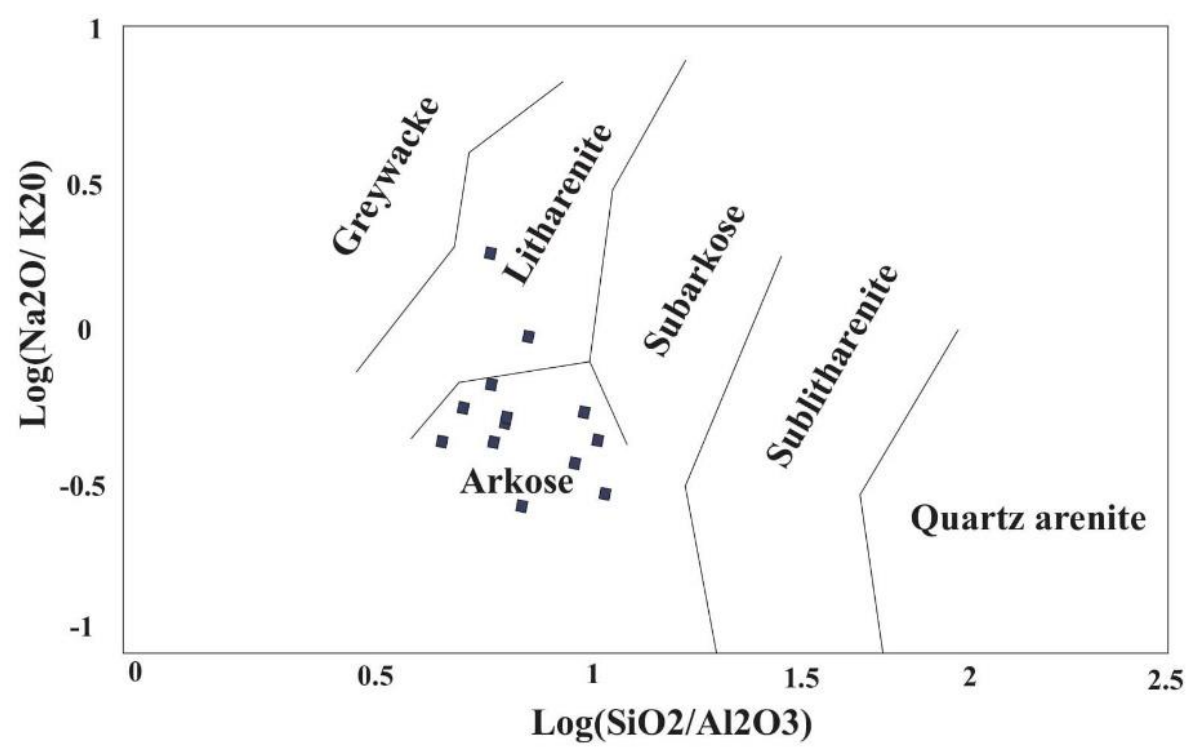

Fig. 3: Chemical classification of sandstone samples based on the Binary diagram Log $\left(\mathrm{SiO} 2 / \mathrm{Al}_{2} \mathrm{O}_{3}\right)$ Vs Log $\left(\mathrm{Na}_{2} \mathrm{O} / \mathrm{K}_{2} \mathrm{O}\right)$ is plotted in the field of arkoses to subarkose (after Pettijohn et al., 1972).

\section{Provenance and Tectonic Setting:}

Dickinson and Suczek (1979) have set forth that information about the tectonic setting of a depositional basin and their associated provenance can be inferred by plotting the detrital frameworks mode of sandstone on QFL and QFL ternary diagram. These ternary diagrams are divided into three main fields representing the type of tectonic setting, or provenance:

1. Continental block Provenances

2. Magmatic arc Provenances

3. Recycled orogen Provenances

The modal analysis of framework component of 15 sandstone sample of the present study was carried out and obtained data were plotted on the QFL diagram. The plot indicates transitional continent and recycled orogen provenance for the sediments. The detritus includes the moderate quartz content and a high ratio of K-feldspar to plagioclase (Fig. 4). 


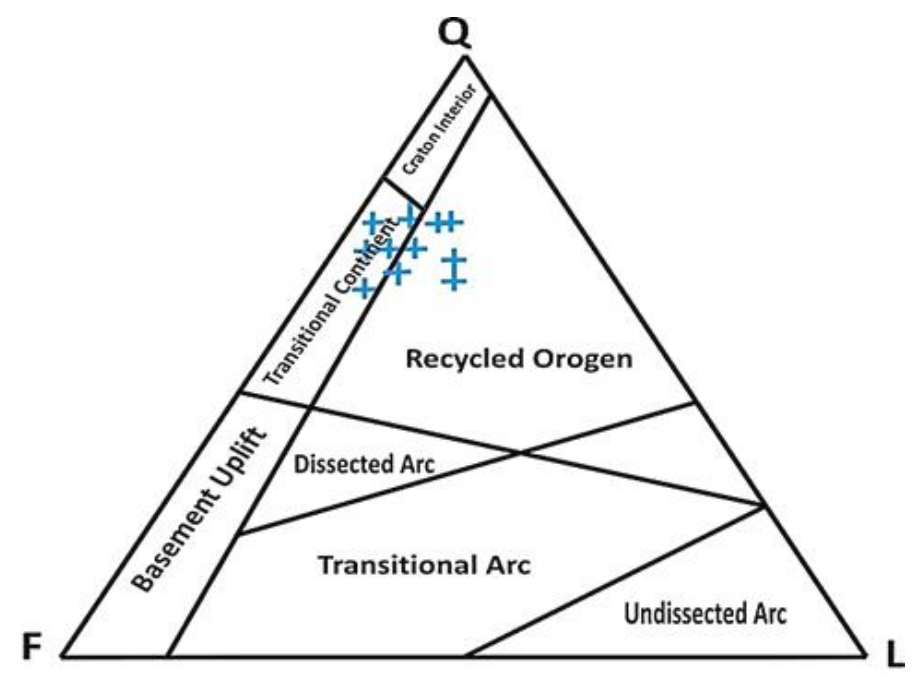

Fig. 4: Q-F-L Tectonic setting discrimination diagram. The plot indicates transitional continent and recycled orogen provenance for the sediments (after Dickinson et al., 1983).

\section{Provenance Discrimination Plot}

This is a binary diagram (Roser and Korsch, 1988) between the discriminant function I and discriminant function II. Where,

Discriminant Function $1=\left(-1.773 \times \mathrm{TiO}_{2} \%\right)+\left(0.607 \times \mathrm{Al}_{2} \mathrm{O}_{3} \%\right)+\left(0.76 \times \mathrm{Fe}_{2} \mathrm{O}_{3} \mathrm{~T} \%\right)$

$+(-1.5 \times \mathrm{MgO} \%)+(0.616 \times \mathrm{CaO} \%)+(0.509 \times \mathrm{Na} 2 \mathrm{O} \%)+(-1.22 \times \mathrm{K} 2 \mathrm{O} \%)+(-9.09)$

Discriminant Function $2=(0.445 \times \mathrm{TiO} \%)+(0.07 \times \mathrm{Al} 2 \mathrm{O} 3 \%)+(-0.25 \times \mathrm{Fe} 2 \mathrm{O} 3 \mathrm{~T} \%)$ $+(-1.142 \times \mathrm{MgO} \%)+(0.432 \times \mathrm{Na} 2 \mathrm{O} \%)+(1.426 \times \mathrm{K} 2 \mathrm{O} \%)+(-6.861)$

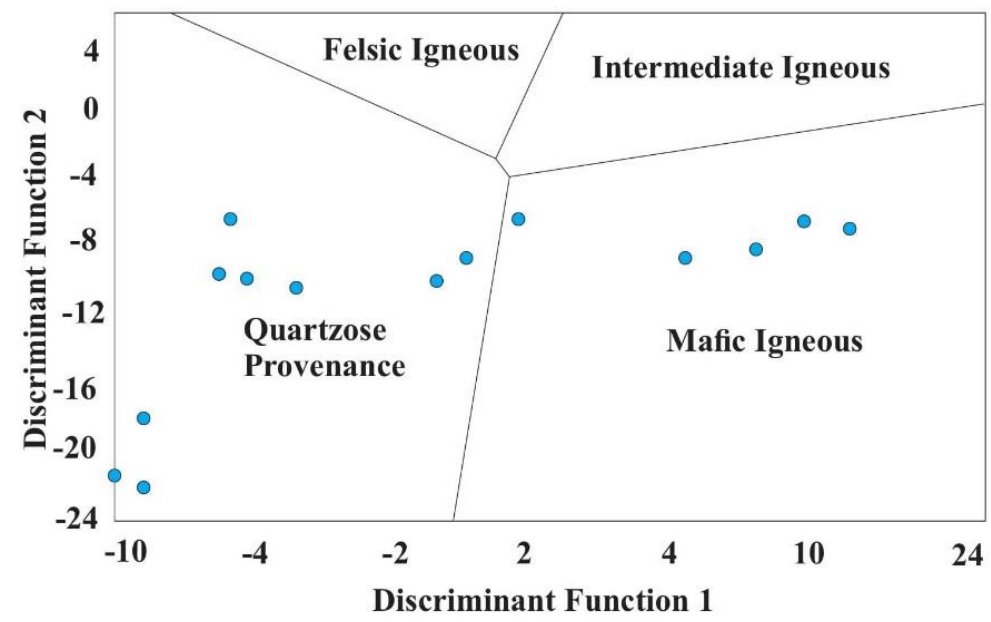

Fig. 5: Discriminant Function diagram for provenance signature shows sandstone falls into the field of quartzose and mafic igneous provenance, indicating the mixed provenance for the siliciclastic sediments (after Roser and Korsch, 1988).

This plot provides the insight into the source rock mineralogy of the siliciclastic sediments on the basis of their chemical composition. This helps to distinguish between different provenances like mafic, intermediate, felsic igneous and quartzose sedimentary rocks. 
Sandstone of the present study falls into the field of quartzose and mafic igneous provenance, this indicates the mixed provenance for the siliciclastic sediments of upper part of the Sandhan Formation (Fig. 5).

\section{$\mathrm{SiO}_{2} / \mathrm{Al}_{2} \mathrm{O}_{3}-\mathrm{K}_{2} \mathrm{O} / \mathrm{Na}_{2} \mathrm{O} \mathrm{Plot}$}

Bhatia (1983) defined this plot based on the chemical analysis of the clastic sediments, which shows similarity to $\mathrm{K}_{2} \mathrm{O} / \mathrm{Na}_{2} \mathrm{O}-\mathrm{SiO}_{2}$ plot, where average data plot in the same pattern. Passive margin sediments are characterized by higher values of both ratios. Active margin sediments depict the lower $\mathrm{SiO}_{2} / \mathrm{Al}_{2} \mathrm{O}_{3}$ ratio with variable low $\mathrm{K}_{2} \mathrm{O} / \mathrm{Na}_{2} \mathrm{O}$ ratio (Mc Lennon et al. 1990). On the Major element-based diagram of Bhatia (1983), Sandstone of the present study is plotted in the field of $A C M$ and PM. Active margin sediments depict the lower $\mathrm{SiO}_{2} / \mathrm{Al}_{2} \mathrm{O}_{3}$ ratio with variable low $\mathrm{K}_{2} \mathrm{O} / \mathrm{Na}_{2} \mathrm{O}$ ratio and Passive margin sediments are characterized by higher values of both the ratio (Fig.6).

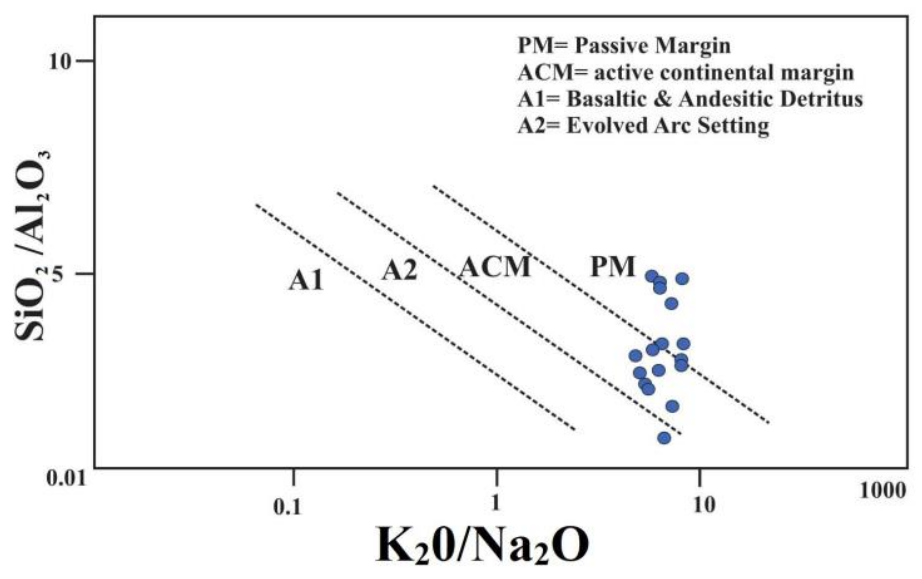

Fig. 6: Tectonic Discriminant diagram showing sandstone is plotted in the field of ACM and PM (after Roser and Korsch, 1986).

\section{Paleo-weathering:}

Weathering involves the physical disintegration and chemical decomposition of the older rocks to produce solid particulate residue and dissolved chemical substance. The major factor which mainly affects the intensity of the weathering includes the source rock composition, duration of weathering, climatic condition and rate of tectonic upliftment of the source region (Condie, 1997). Although physical, chemical and biological processes are involved in the weathering but the chemical process is by far the most important. It strongly affects the major element geochemistry and mineralogy of the siliciclastic sediments (Nesbitt and Young, 1982). Feldspar and volcanic glass material constitute most of the labile material of the earth upper crust and the weathering of these material yields the clay minerals (Taylor and McLennan, 1985; Nesbitt and Young, 1984, 1989). Labile elements like $\mathrm{Ca}, \mathrm{Na}, \mathrm{K}$, are largely removed from the source rock during the chemical weathering. The amount of these elements surviving in soil profiles and in sediments derived from them is a sensitive index of the intensity of chemical weathering (Nesbitt et al., 1997).

There are various methods to quantify the intensity of weathering of the source rock. Based on the molecular proportion of the mobile and immobile element oxides $\left(\mathrm{Na}_{2} \mathrm{O}, \mathrm{CaO}, \mathrm{K}_{2} \mathrm{O}\right.$, and $\mathrm{Al}_{2} \mathrm{O}_{3}$ ) some indices of weathering has been tendered. Chemical Index of Alteration $(\mathrm{CIA})$ (Nesbitt and Young, 1982) is well-established method among the variously proposed indices to quantify the extent of chemical alteration that has taken place in the source area. 
CIA can be calculated by using the following formula:

$$
\mathrm{ClA}=\left(\mathrm{Al}_{2} \mathrm{O}_{3}\right) /\left(\mathrm{Al}_{2} \mathrm{O}_{3}+\mathrm{CaO}^{*}+\mathrm{Na}_{2} \mathrm{O}+\mathrm{K}_{2} \mathrm{O}\right) * 100
$$

Where $\mathrm{CaO}^{*}=$ Calcium content from the silicate fraction of the sediments (correction must be made for carbonate and phosphate contents).

Plagioclase Index of Alteration (PIA; Fedo et al., 1995) and Chemical index of Weathering (CIW) (Cullers, 2000) is another method to access the source rock weathering and elemental distribution during the diagenesis.

$$
\begin{aligned}
\mathrm{PIA} & =\left\{\left(\mathrm{Al}_{2} \mathrm{O}_{3}-\mathrm{K}_{2} \mathrm{O}\right) /\left(\left(\mathrm{Al}_{2} \mathrm{O}_{3}-\mathrm{K}_{2} \mathrm{O}\right)+\mathrm{CaO}^{*}+\mathrm{Na}_{2} \mathrm{O}\right)\right\} \times 100 \\
\mathrm{CIW} & =\left\{\mathrm{Al}_{2} \mathrm{O}_{3} /\left(\mathrm{Al}_{2} \mathrm{O}_{3}+\mathrm{CaO}^{*}+\mathrm{Na}_{2} \mathrm{O}\right)\right\} \times 100
\end{aligned}
$$

Following the procedure provided by the McLennan (1993), CIA, PIA, CIW values have been calculated and obtained values is given in the table (Table-1)

According to CIA values degree of source weathering varies from 67.14 to $79.17 \%$ (average $76.048 \%$ ). PIA values indicate intensity of weathering varies from 58.37 to $87.18 \%$ (average 80.43). CIW values suggest the source weathering in range from 63.86 to $89.86 \%$ (average 83.86).
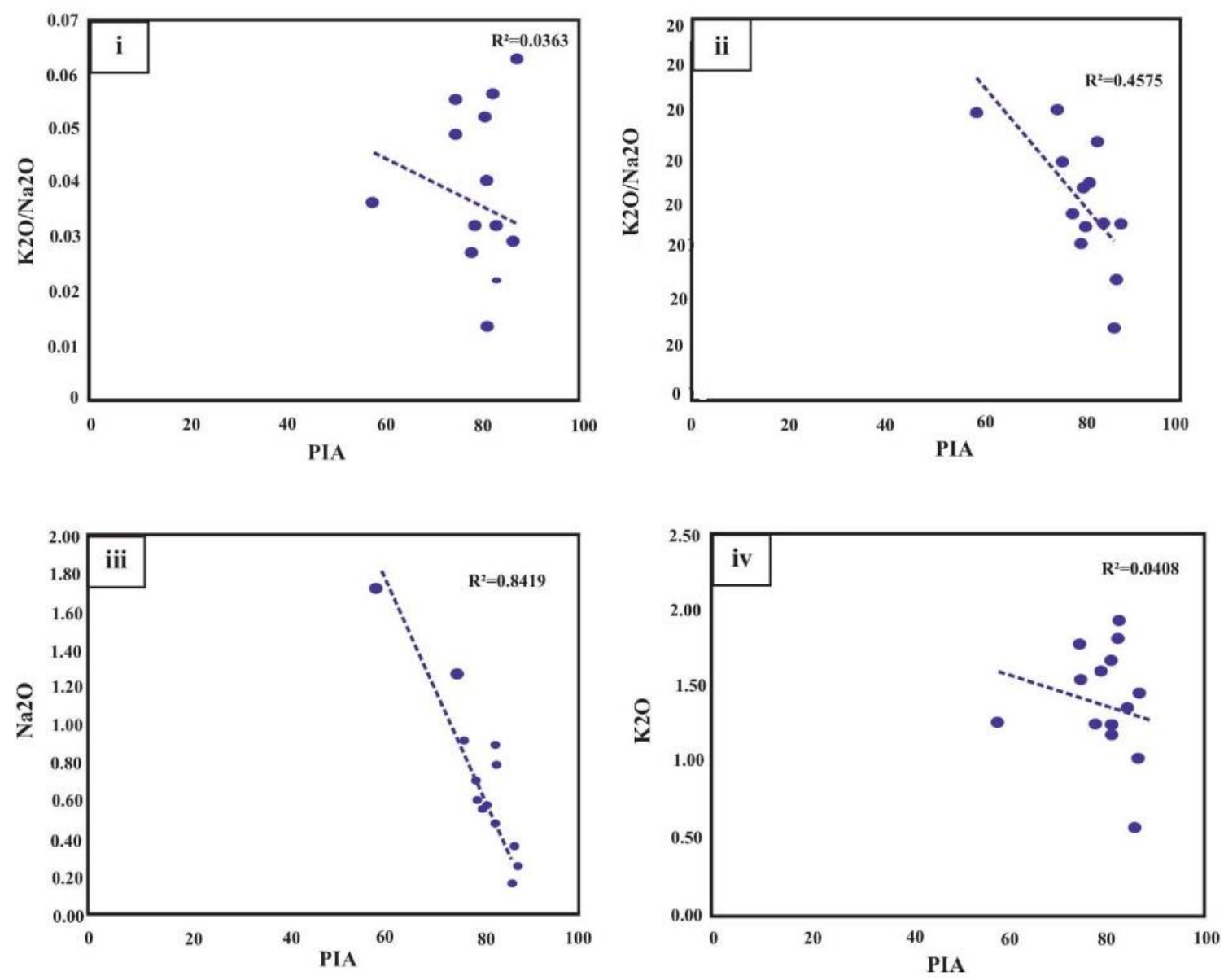

Fig. 7: Bivariate plots depicting the mobility of elements during progressive weathering of source rock. (i) $\mathrm{K}_{2} \mathrm{O} / \mathrm{Na}_{2} \mathrm{O}$ vs PIA (ii) $\mathrm{K}_{2} \mathrm{O}+\mathrm{Na}_{2} \mathrm{O}$ vs PIA (iii) $\mathrm{Na}_{2} \mathrm{O}$ vs PIA (iv) $\mathrm{K}_{2} \mathrm{O}$ vs PIA. 
Average values of the above weathering indices indicate moderate to intense weathering of the source material. PIA values suggest the destruction of Feldspar during source weathering. During an initial stage of weathering $\mathrm{Ca}$ is more rapidly leached than $\mathrm{Na}$ and $\mathrm{K}$. this is due to the destruction of feldspar among which plagioclase is more preferentially removed than Kfeldspar (Nesbit and Young, 1984) (Fig. 7). The mobility of element during weathering may be visualized by bivariate plots involving $\mathrm{Na}_{2} \mathrm{O}, \mathrm{K}_{2} \mathrm{O}, \mathrm{CaO}, \mathrm{SiO}_{2}$, and $\mathrm{PIA}$. In the graph, $\mathrm{K}_{2} \mathrm{O} / \mathrm{Na}_{2} \mathrm{O}$ decreases with increasing value of PIA and in $\left(\mathrm{Na}_{2} \mathrm{O}+\mathrm{K}_{2} \mathrm{O}\right) \mathrm{Wt} \%$ vs PIA diagramme, the total content of alkalis decreases with increasing value of PIA. Weak relation between alkalis and PIA may be attributed due to the presence of K-bearing minerals.

\section{A-CN-K Diagram}

The molar proportion of $\mathrm{Al}_{2} \mathrm{O}_{3}, \mathrm{~K}_{2} \mathrm{O}, \mathrm{CaO}^{*}$. And $\mathrm{Na}_{2} \mathrm{O}$ are plotted to on the A-CN-K diagramme (Nesbitt and Young, 1982, 1984), where, $\mathrm{A}=\mathrm{Al}_{2} \mathrm{O}_{3}, \mathrm{CN}=\mathrm{CaO}^{*}+\mathrm{Na}_{2} \mathrm{O}, \mathrm{K}=\mathrm{K}_{2} \mathrm{O}$. This plot is very useful in evaluating the mobility of the element during the weathering and modification that have occurred during the post-depositional changes.

This plot defines a weathering trend parallel to the $\mathrm{A}-\mathrm{CN}$ line because the $\mathrm{Ca}$ and $\mathrm{Na}$ are more mobile during the weathering than the mobility of K (Nesbit and Young, 1984). Because of high mobility during the weathering processes, $\mathrm{Ca}$ and $\mathrm{Na}$ are leached out more rapidly from the plagioclase and volcanic glass than the removal of $\mathrm{K}$ from the microcline and volcanic glass. It is possible to trace these trends backward to the feldspar join to find out the source composition (Fedo et al., 1995). Studied samples fall between the basaltic and andesitic field (Potential ultimate source). All the samples are plotted in the middle which indicates moderate weathering (Fig. 8).

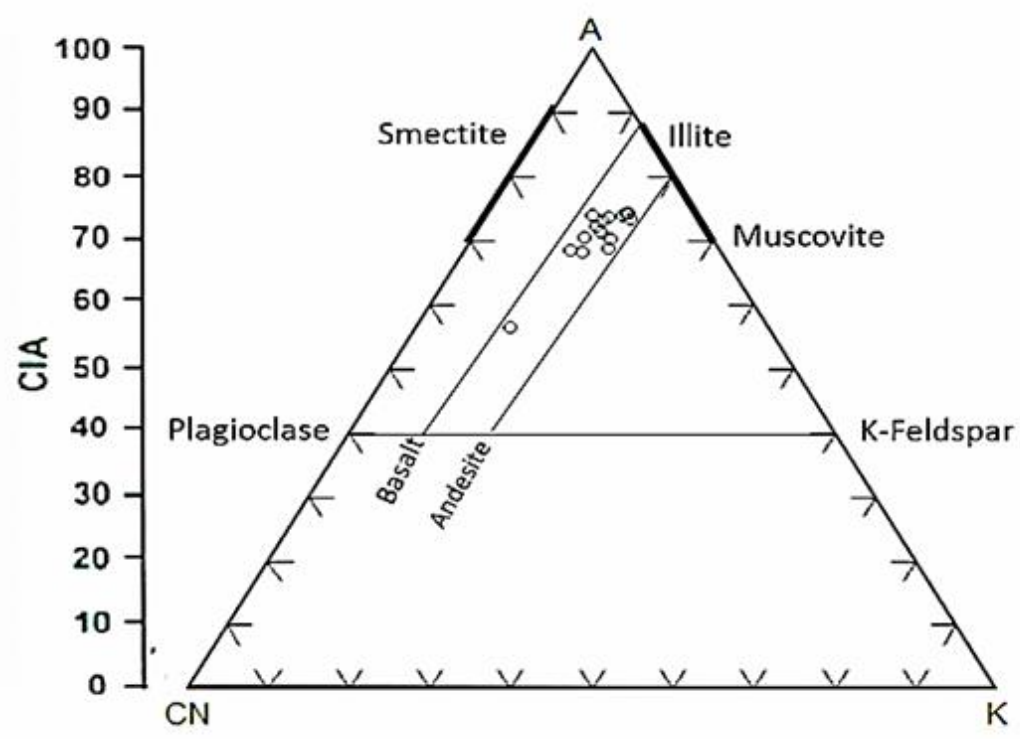

Fig. 8: $A-C N-K$ ternary weathering diagram $A=\mathrm{Al}_{2} \mathrm{O}_{3}, \mathrm{CN}=\mathrm{CaO}+\mathrm{Na}_{2} \mathrm{O}, \mathrm{K}=\mathrm{K}_{2} \mathrm{O}$ (All in molar proportion). All the samples are plotted in the middle which indicates moderate weathering (Nesbit and Young, 1984).

\section{Sediment Maturity and Paleo-climatic Condition:}

$\mathrm{SiO}_{2} / \mathrm{Al}_{2} \mathrm{O}_{3}$ ratio is used as an indicator of sediment maturity because of its sensitiveness to the sediment recycling and the weathering processes (Table-1). A sandstone composed mainly of the quartz considered compositionally mature, whereas sandstone that contains abundant unstable minerals (feldspars, mafic minerals, and lithics) is compositionally immature. Thus quartz retained preferentially to feldspars, mafic minerals and lithics in the sediments as 
maturity increases (Roser and Korsch, 1986). Values of $\mathrm{SiO}_{2} / \mathrm{Al}_{2} \mathrm{O}_{3}$ ratio is $>5.0$, indicate the progressive mature nature of the sandstone.

Climatic condition prevailing during the sediment deposition in the basin have pronounced effects as warm and humid climate are more favorable for the chemical weathering and is marked by the presence of altered feldspar (Folk, 1980). To constrain the climatic condition prevailed during the siliciclastic sedimentation Suttner and Dutta (1986) introduced a binary $\mathrm{SiO}_{2}$ wt.\% versus $\left(\mathrm{Al}_{2} \mathrm{O}_{3}+\mathrm{K}_{2} \mathrm{O}+\mathrm{Na}_{2} \mathrm{O}\right)$ wt.\% diagram. On this diagram, sandstone samples plot mainly in the field of arid climate (Fig. 9).

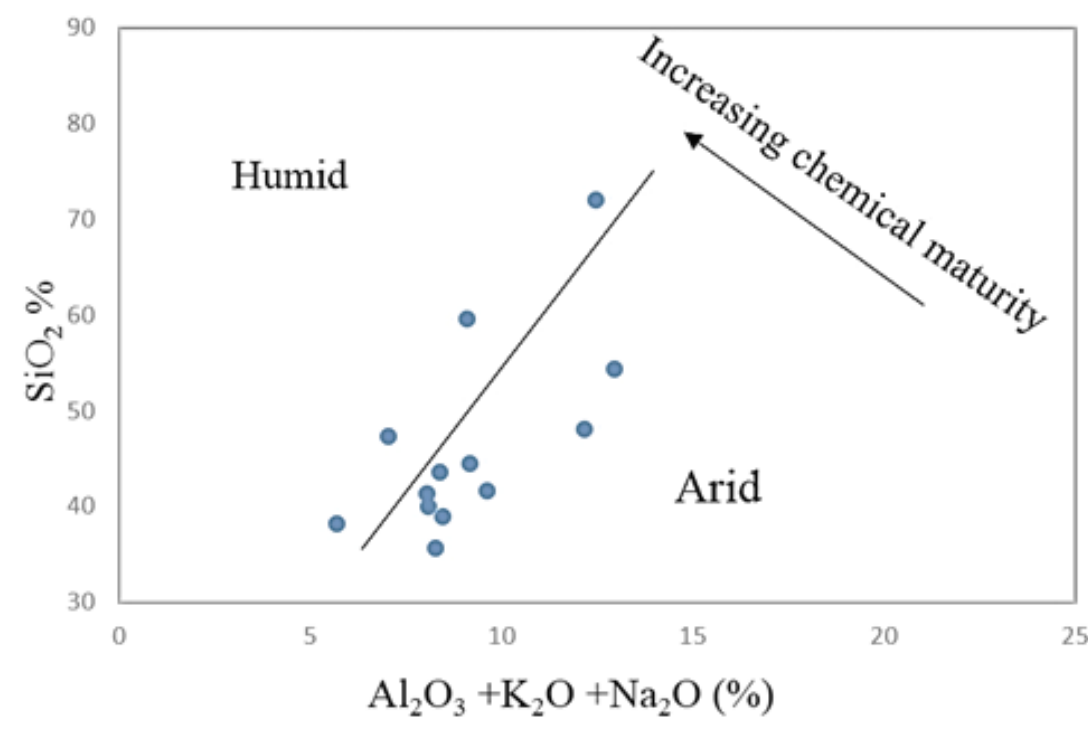

Fig. 9: Chemical maturity of sandstone and their Paleo environment of Deposition based on the $\mathrm{SiO}_{2}$ vs $\mathrm{Al}_{2} \mathrm{O}_{3}+\mathrm{K}_{2} \mathrm{O}+\mathrm{Na}_{2} \mathrm{O}$ wt. \% bivariate diagram showing sandstone samples plot mainly in the field of arid climate (after Suttner and Dutta, 1986).

\section{Petrography:}

Petrography is the classification and description of rocks. Petrography provides a precise percentage of the various minerals and their texture. Mineralogical studies provide very important information related to the provenance (Fatima and Khan, 2012).

The sandstone samples of Sandhan Formation are soft and less compact. Major categories of grains identified include monocrystalline quartz $\left(Q_{m}\right)$, polycrystalline quartz $\left(Q_{p}\right)$, K-feldspar, plagioclase, mica, and clasts (rock fragment).

\section{Major Constituent}

(a) Quartz: The sandstone of Sandhan Formation mainly consists of quartz. Quartz is medium to fine-grained, with occasional occurrence of large grains of quartz. Quartz grains have subangular to sub-spherical to rounded outline, however, few angular boundaries were also observed. Most of the quartz grains are fresh and clean. While some of them are dirty and display shades of reddish colors due to staining of ferruginous cementing material. Some of the quartz grains show fractures. Quartz occurs in both as monocrystalline and polycrystalline grains. The monocrystalline variety is much more abundant than the polycrystalline. Most of the quartz grain shows straight outline (Fig.10). 

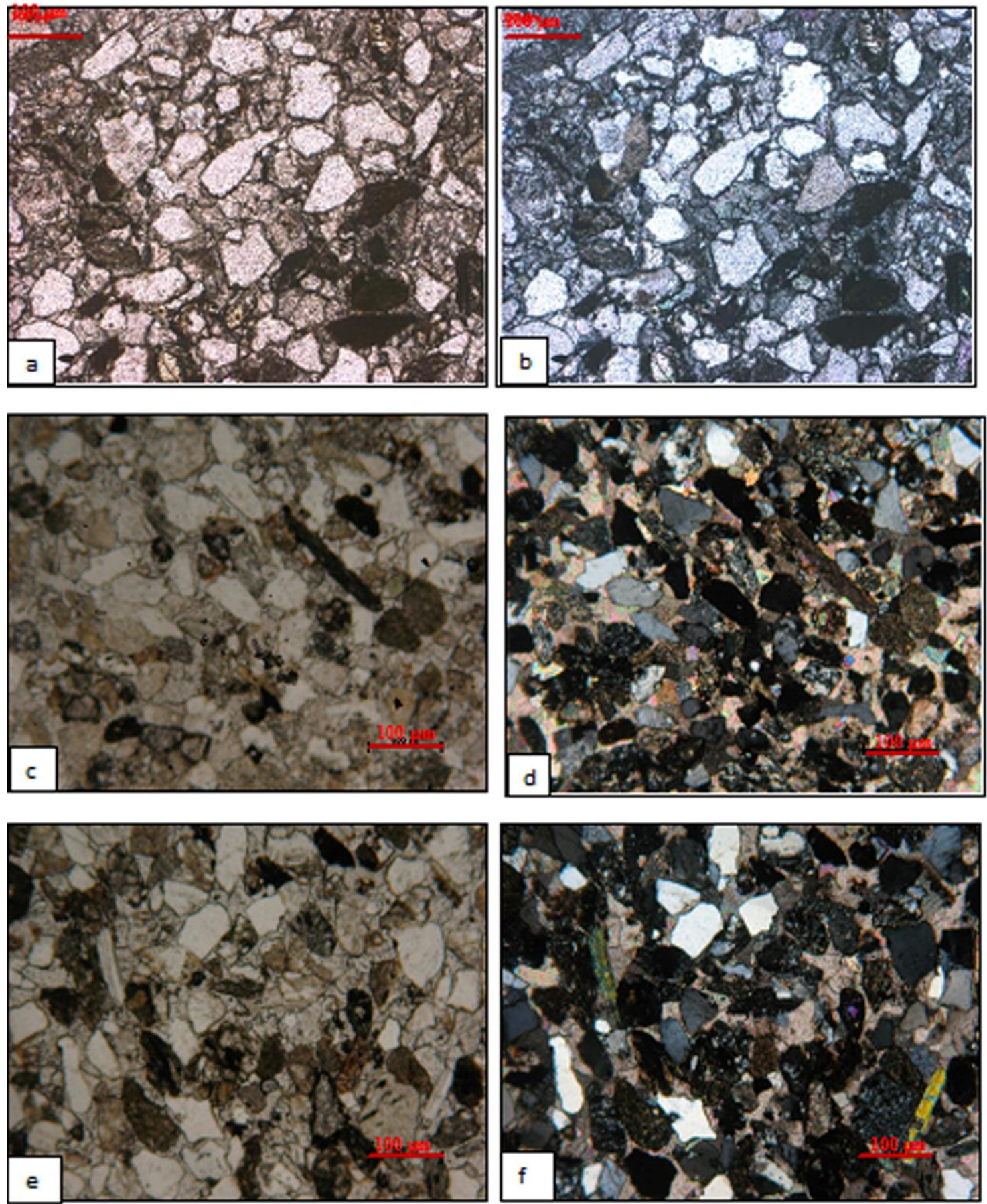

Fig. 10: a) \& b) Sandstone under Plane Polar Light (PPL) and Cross Polar Light (CPL) respectively, moderately sorted sandy bar sandstone with Quartz and Feldspar as a framework grains. Framework grains are sub rounded to sub angular. Calcite occurs as a matrix. c) \& d) Sandstone under Plane Polar Light (PPL) and Cross Polar Light $(\mathrm{CPL})$ respectively. Quartz and Feldspar are the major framework mineral with some lithic fragments. Quartz grains are mainly monocrystalline. Framework grains are sub rounded. Cementing material is calcite. e) \& f) Fine grained moderately sorted sandstone under PPL and CPL respectively, Framework grains are embedded in calcitic cement. Muscovite flakes are also present. 
(b) Feldspars: The feldspars are the second most abundant and important constituent. Almost all the studied samples contain appreciable amounts of feldspars. Most of the feldspar grains are of medium size. They are mostly sub-spherical in shape. The grains of feldspar are not very clean as they show alteration to clay minerals. Some feldspar grains are fractured and the fractures are filled with calcareous cement. Alkali feldspar is by far the most abundant type of feldspar, plagioclase, and microcline also occur in the samples is minor constituents. Plagioclase occurs in small amounts and its grains show the characteristic albite polysynthetic twinning. Microcline is rather rare and occurs in the form of small grains and most of the microcline grains display the diagnostic cross-hatched twinning.

\section{Accessory Constituents}

These include rock fragments and mica principally, muscovite. Rock fragments are generally considered to be one of the common constituents of sandstones, the studied samples have a considerable amount of rock fragment. The rock fragments occur as medium grains outlines and include igneous type. It also includes chert. The grains of chert is fine to medium in size, sub-spherical and have sub-angular to rounded boundaries. Small amounts of muscovite occur as flakes in the studied samples.

\section{Mineral Cement}

Three type of cementing material observed in the sandstone sample which includes calcite, iron oxide, and silica.

(a) Calcite cementation: Three main types of calcite types of cement are observed:

(i) Poikilotopic calcite crystal: It is observed as large single crystal up to several $\mathrm{mm}$ across which have enveloped many quartz grains. Cementation varies from uniform to patchy distribution. At some places, grains appear to float in the cement that occur principally due to replacement. Some quartz grains are corroded and etched at their margin due to calcite cementation.

(ii) Micritic calcite: Occurs as a dense framework among the grains. Particles size are mostly $<0.02 \mathrm{~mm}$

(iii) Calcite spar: It is observed as a large crystal of calcite, commonly on order of 0.02 to $0.1 \mathrm{~mm}$. They are distinguished from micrite by their larger size and clarity.

(b) Iron oxide cement: This type of cement occurs in the channel cut sediments and characteristics of the fluvial environment. It occurs as a thin coating around the grains and gives red colors to the grains. The probable source of ferruginous cement in observed samples are the alteration of ferruginous mineral of a volcanic source (Deccan volcanic source).

(c) Silica cementation: It occurs as a minor amount in the studied samples and mostly represents marine facies. It principally occurs as a quartz overgrowth (precipitated around the quartz grains and is in optical continuity).

(d) Sorting: The degree of sorting varies in different facies. Channel sands are ill-sorted. Whereas the bar sands are moderately sorted. A decrease in grain size has also been documented in the thin section where the thin sections representing the upper/downstream sections of the bar deposits consisting of finer sediments as compared to the coarser sands lower/upstream bar deposits. 


\section{Diagenetic Feature in Fluvial Sandstone}

The fluvial sandstones are characterized by medium-grained poorly sorted. Main diagenetic features identified in the fluvial sediments are.

Cementation: Calcite is the principal cementing material in fluvial sandstone. The calcium ions for calcite cementation were most likely derived by the meteoric water flux into the sandstone. Calcite cement in fluvial sandstone typically includes dense micritic texture within which scattered quartz grains are embedded. The microcrystalline isopacheous coating also observed along detrital grains. Calcite occurs as poikilitic crystals which tend to fill relative small inter-granular pores between tightly packed framework grains (Fig. 11).
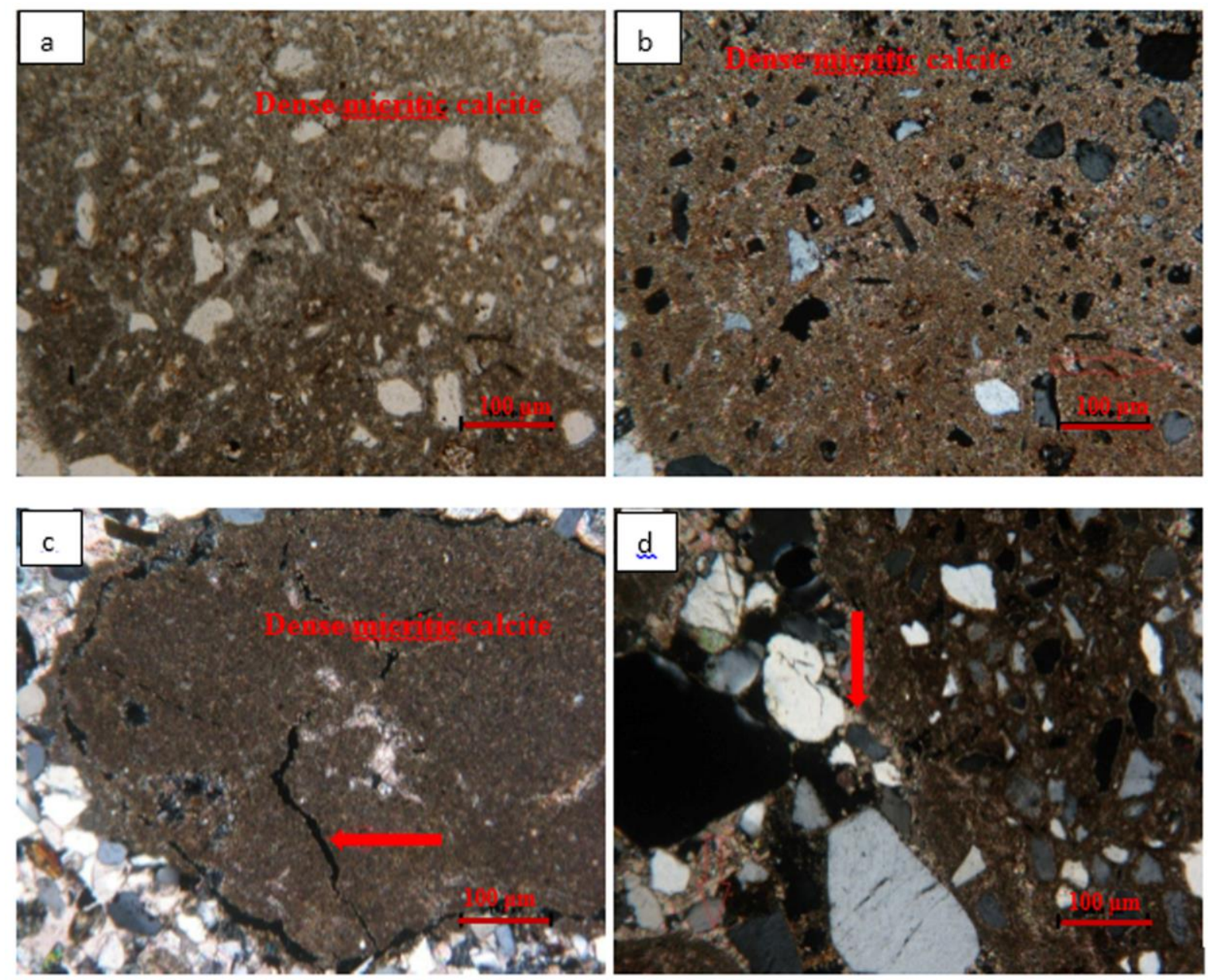

Fig. 11: Diagenetic features of fluvial sandstone, a) and b) Sandstone under the PPL and CPL respectively, with dense micritic calcite with embedded framework grains. (c) Dissolution of dense micritic calcite (d) Microcrystalline isopacheous coating also observed along detrital grains.

Dissolution: Dissolution of dense micritic calcite is observed on a large scale. Which lead to increase in porosity. Thus the porosity observed in the sandstone of Sandhan Formation includes the primary inter-granular porosity, secondary dissolution porosity, and fracture porosity. 


\section{Modal Analysis}

Nearly $60 \%$ of total framework grains are quartz. These grains are sub angular to sub rounded. Amount of feldspar ranges from 20-30\%. Feldspar grains are sub spherical to sub angular in shape. Lithic fragments appear in fewer quantities (1-8\%). Observed wt. \% of the grains were plotted on the QFL plot to classify the sandstone. From QFL classification scheme sandstone samples are classified as sub-arkose to arkose (Fig.12).

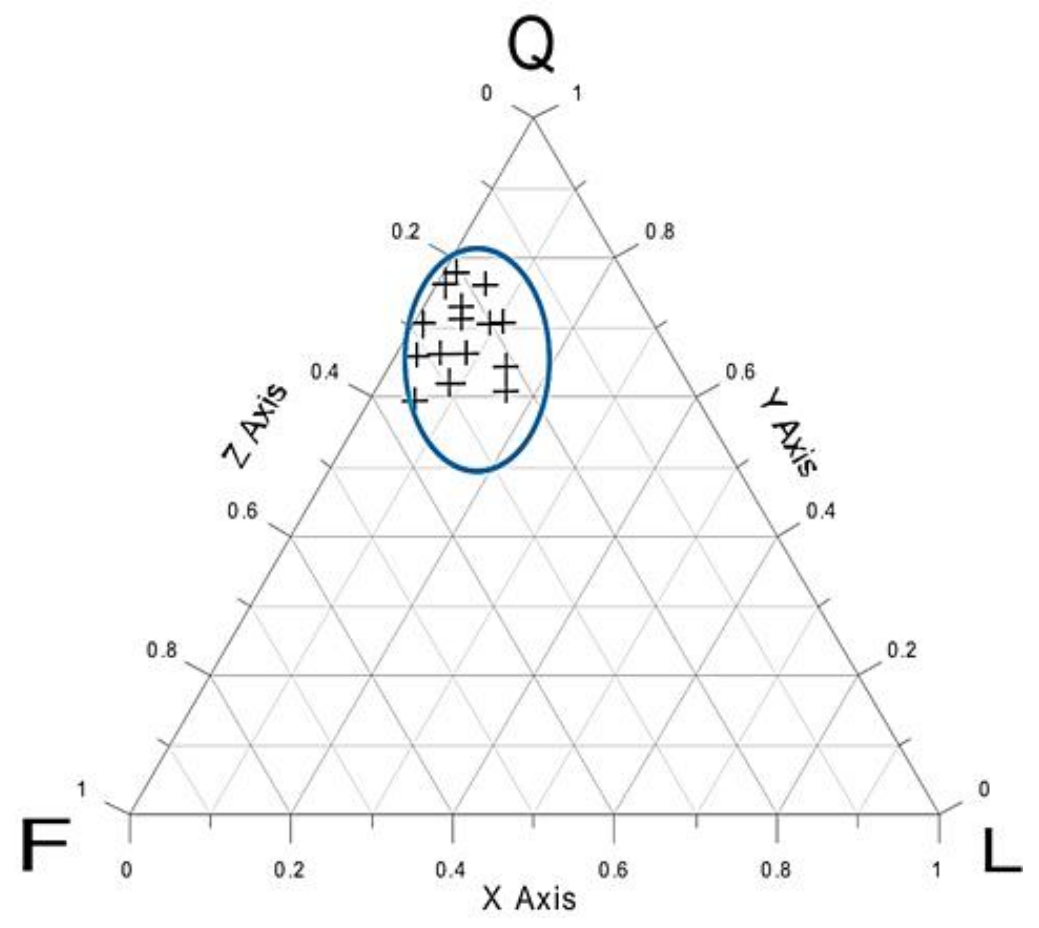

Fig. 12: QFL classification plot of fluvial sandstone samples. Sandstone samples are classified as sub-arkose to arkose.

\section{DISCUSSION}

The upper part of the Sandhan Formation marks the end of sedimentation on the onland part of Kutch basin (Biswas, 1992). It is represented by the fluvial succession and marks the shift of environment from the shallow marine environment at the lower part to fluvial continental deposits at the upper part (Shekhar et al., 2018). The type section of the Sandhan Formation is exposed along the cliff and banks of Kankawati River. Process-based facies analysis was carried out on the upper part of the Sandhan Formation interpreted the depositional environment. The lower boundary which demarcates the transition from a shallow marine environment to continental transition was identified. This boundary is demarcated by prominent boulders bed overlain by the stacked channel sheet sandstone bodies. The boulder bed is resting over the tabular cross-stratified sandstone of barrier Bar facies of lagoon sediments. The immediate incision of the fluvial channel above barrier bar is indicative of abrupt facies break which argues for relative sea level fall. The upper boundary with overlying Sub-recent sediments is characterized by a thick and regional occurrence of paleosol horizon characterized by abundant root penetration structures and associated calcretes sediments (Shekhar et al., 2018). The thick formation of paleosol requires landscape stability association with physical, chemical and biological transformation of exposed sediments, thus indicates an extensive episode of nondeposition/unconformity. The development of paleosol in marginal marine/shallow marine environments is controlled by base-level fall and subaerial exposure of shelf (Lander et al., 1991; 
Webb, 1994; Wright, 1994). The absence of complete open marine and estuarine sediment inter-tonguing with fluvial sediments and high energy condition inferred from the above sedimentological attributes suggests that the deposition of the upper part of the Sandhan Formation took place in unincised, unconfined gravel-bed braided river system. The abrupt fall in relative sea-level in association with highstand wedge may have contributed required slope to develop the braided river system. The braided fluvial system has developed on the resultant exposure of the large part of the continental shelf.

The chemical and mineralogical composition of the framework grains and the cementing material makes the composition of the siliciclastic sedimentary rock. The chemical and mineralogical compositions of clastic sedimentary rocks are controlled by various factors including source rock composition, weathering, erosion, transportation, and sedimentation processes (McLennan et al., 1993). The framework grains of coarse clastic sediments are mainly the residue of weathered (crystalline or detrital) parent rock whereas clay minerals, the dominant component of the fine-grained sediments are mainly formed by the weathering of unstable minerals. The main controlling factor which causes the weathering and erosion process of the source rock includes the climate and topography in the provenance area. Unstable minerals like feldspar and mafic minerals get weathered out easily as compared to the stable minerals such as quartz and zircon. The continuous weathering causes the depletion of the unstable components and comparative enrichment of the stable minerals as well as clay minerals in the detrital spectrum. Abrasion and sorting process during the transportation also modifies the compositional and textural characteristics of initial detritus. Initial sediments characteristic gets further modified by the mixing of detritus from multiple sources. Ultimately detritus gets deposited in different depositional setting, characterized by the different prevailing sedimentary environments. A sedimentary environment is a specific depositional setting which is unique in term of physical, chemical and biological characteristics, which can further affect the composition of detritus. At the site of deposition environmental signature may be added to the sediment. Detrital phases may subject to further alteration by post-depositional diagenetic processes. These post-depositional processes are largely controlled by the composition and texture of the sediment (grain-size distribution, grain shapes and packing density control permeability). The mineralogical and chemical composition of the clastic sediments reflects the provenance composition, relief and entire history of its modification by weathering, recycling, transport mixing, deposition, and diagenesis. Introduction of the Point-Counting device changed the way of looking in to the mineralogy of the sediments. It made possible to measure the modal composition from the thin section. Subsequently, it was established that modal composition of sand is largely controlled by Plate tectonics (Dickinson and Suczek, 1979). Cox et al. (1995) pointed out that sediments are not one to one image of their source, instead, it is governed by many other factors rather than parent lithology. Clastic sediments are made up of detrital grains and fine-grained sediments. Climate and topography, vegetation, weathering are the main factors which affect the final composition of the sediments.

Geochemical analysis of sandstone samples by using XRF technique of ten major element oxides $\left(\mathrm{SiO}_{2}, \mathrm{TiO}_{2}, \mathrm{Al}_{2} \mathrm{O}_{3}, \mathrm{FeO}, \mathrm{MnO}, \mathrm{MgO}, \mathrm{CaO}, \mathrm{Na}_{2} \mathrm{O}, \mathrm{K}_{2} \mathrm{O}\right.$, and $\left.\mathrm{P}_{2} \mathrm{O}_{5}\right)$ and twelve trace elements ( $\mathrm{Cu}, \mathrm{Cr}, \mathrm{Ba}, \mathrm{Nb}, \mathrm{Rb}, \mathrm{Sr}, \mathrm{Sc}, \mathrm{Ni}, \mathrm{Zn}, \mathrm{Zr}, \mathrm{V}$, and $\mathrm{Y}$ ) gives the overall idea of the geochemical setup of the upper part of the Sandhan Formation. Following scheme proposed by Pettijhon et al. (1972) on the sandstone samples, in the bivariate diagram $\mathrm{Log}\left(\mathrm{SiO}_{2} / \mathrm{Al}_{2} \mathrm{O}_{3}\right)$ versus Log $\left(\mathrm{Na}_{2} \mathrm{O} / \mathrm{K}_{2} \mathrm{O}\right)$ diagram sandstone samples are plotted in the field of arkose to subarkose. For the analysis of provenance and tectonic setting the modal analysis of framework component of samples, when plotted on the QFL diagram the plot indicate transitional continent and recycled orogen provenance for the sediments. The detritus includes the moderate quartz content and a high ratio of K-feldspar to plagioclase. The Provenance Discrimination Plot which provides the insight into the source rock mineralogy of the siliciclastic sediments on the basis of their chemical composition, Sandstone samples falls into the field of quartzose and mafic igneous provenance, this indicates the mixed provenance for the siliciclastic sediments of upper 
part of the Sandhan Formation. On the Major element-based diagram of Bhatia (1983), Sandstones are plotted in the field of ACM and PM. Active margin sediments depict the lower $\mathrm{SiO}_{2} / \mathrm{Al}_{2} \mathrm{O}_{3}$ ratio with variable low $\mathrm{K}_{2} \mathrm{O} / \mathrm{Na}_{2} \mathrm{O}$ ratio and passive margin sediments are characterized by higher values of both the ratio.

Average values of the Chemical Index of Alteration (CIA) weathering indices indicate moderate to intense weathering of the source material. PIA values suggest the destruction of Feldspar during source weathering. During an initial stage of weathering $\mathrm{Ca}$ is more rapidly leached than $\mathrm{Na}$ and $\mathrm{K}$. This is due to the destruction of feldspar among which plagioclase is more preferentially removed than K-feldspar (Nesbit and Young, 1984). In evaluating the mobility of the element during the weathering and modification that have occurred during the post-depositional changes, the studied samples in A-CN-K Diagram falls between the basaltic and andesitic field (Potential ultimate source). All the samples are plotted in the middle which indicates moderate weathering. For the analysis of sediment maturity, the values of $\mathrm{SiO}_{2} / \mathrm{Al}_{2} \mathrm{O}_{3}$ ratio is $>5.0$, which indicates the progressive mature nature of the sandstone. In the binary $\mathrm{SiO}_{2}$ wt.\% versus $\left(\mathrm{Al}_{2} \mathrm{O}_{3}+\mathrm{K}_{2} \mathrm{O}+\mathrm{Na}_{2} \mathrm{O}\right)$ wt.\% diagram by Suttner and Dutta (1986) which constrain the climatic condition prevailed during the siliciclastic sedimentation for the Paleo-climate analysis, the sandstone samples plot mainly in the field of arid climate.

The present study is first attempt to examine the geochemical and petrographic characteristic of the upper part of the Sandhan Formation. Major element oxides, trace element data of the sedimentary rocks along with petrographic studies were undertaken. The generated geochemical data in combination with petrographic data utilized to interpret the provenance, tectonic setting, paleo weathering and paleoclimate condition of the upper part of the Sandhan Formation prevailing at the time of their deposition.

\section{CONCLUSIONS}

1. The field-based sedimentological studies along the type section of the Sandhan formation, suggests that lower part of the Sandhan Formation is deposited in the shallow marine environment and deposition of the $\sim 157 \mathrm{~m}$ thick upper part taken place in the continental fluvial environment.

2. Based on the petrographic analysis and modal counting of the selected samples of sandstone, it is classified as arkosic to subarkosic in nature, further corroborated by the geochemical classification.

3. The mixed provenance (quartzose sedimentary and mafic igneous) for the sediments is interpreted. The arid paleoclimatic condition, moderate to an intense paleo-weathering condition in both active and passive paleotectonic setting is interpreted.

4. Abrupt fall in the relative sea level in association with highstand prism may possibly have provided the required slope for a braided river system to develop on the resultant large exposed region of the continental shelf.

Acknowledgments: The author (Pramod Kumar) acknowledges the financial support provided by University of Delhi under Research and Development Grants during 2014 and 2015. We acknowledge Prof. M. G. Thakkar and Gaurav Chauhan (KSKV Kutch University) for their support during the field. 
Table-1: Major Element Oxide \% data of the sandstone samples analyzed by XRF on pressed powdered pellets, ratios of $\mathrm{K}_{2} \mathrm{O} / \mathrm{Na}_{2} \mathrm{O} ; \mathrm{SiO}_{2} / \mathrm{Al}_{2} \mathrm{O}_{3}$ and calculated weathering index (CIA, PIA and CIW) of sandstone samples of the Upper part of the Sandhan Formation.

\begin{tabular}{|c|c|c|c|c|c|c|c|c|c|c|c|c|c|c|c|}
\hline Sample & S-1 & S-2 & S-3 & S-4 & S-5 & S-6 & S-7 & S-8 & S-9 & S-10 & S-11 & S-12 & S-13 & S-14 & S-15 \\
\hline $\mathrm{TiO}_{2}$ & 0.50 & 0.52 & 0.39 & 0.34 & 0.30 & 0.33 & 0.33 & 0.29 & 0.45 & 0.47 & 0.56 & 0.42 & 0.44 & 0.60 & 0.46 \\
\hline $\mathrm{MgO}$ & 0.97 & 6.16 & 1.71 & 13.29 & 1.20 & 1.11 & 3.20 & 12.24 & 2.93 & 2.82 & 5.81 & 6.46 & 4.71 & 9.66 & 4.31 \\
\hline $\mathrm{Al}_{2} \mathrm{O}_{3}$ & 4.43 & 9.46 & 6.26 & 2.56 & 6.85 & 5.40 & 6.27 & 4.13 & 9.42 & 6.28 & 10.26 & 6.54 & 6.15 & 6.33 & 7.17 \\
\hline $\mathrm{K}_{2} \mathrm{O}$ & 1.03 & 1.92 & 1.44 & 0.58 & 1.66 & 1.16 & 1.60 & 1.01 & 1.79 & 1.24 & 1.81 & 1.35 & 1.27 & 1.25 & 1.55 \\
\hline $\mathrm{CaO}$ & 32.33 & 10.05 & 25.80 & 27.68 & 14.22 & 22.71 & 23.32 & 20.71 & 2.28 & 24.37 & 7.27 & 14.95 & 15.91 & 15.16 & 18.84 \\
\hline $\mathrm{P}_{2} \mathrm{O}_{5}$ & 0.04 & 0.09 & 0.05 & 0.09 & 0.05 & 0.05 & 0.06 & 0.17 & 0.07 & 0.06 & 0.07 & 0.10 & 0.08 & 0.08 & 0.06 \\
\hline $\mathrm{MnO}$ & 0.04 & 0.14 & 0.07 & 0.17 & 0.07 & 0.06 & 0.14 & 0.25 & 0.05 & 0.11 & 0.09 & 0.15 & 0.12 & 0.27 & 0.08 \\
\hline $\mathrm{CIA}$ & 77.58 & 77.79 & 77.66 & 77.58 & 75.11 & 76.49 & 73.94 & 76.77 & 75.48 & 77.53 & 79.17 & 78.04 & 67.14 & 76.45 & 74.53 \\
\hline PIA & 87.17 & 82.85 & 87.004 & 86.09 & 80.97 & 80.92 & 79.29 & 86.67 & 75.03 & 81.29 & 82.60 & 84.12 & 58.373 & 78.40 & 75.74 \\
\hline CIW & 89.86 & 85.84 & 89.68 & 88.89 & 84.88 & 84.38 & 83.71 & 89.59 & 78.76 & 84.41 & 85.22 & 86.97 & 63.86293 & 81.89 & 79.93 \\
\hline
\end{tabular}

\section{REFERENCES}

Basu, A., Young, S.W., Suttner, L.J., James, W.C and Mack, G.H. (1975) Re-evaluation of the use of undulatory extinction and polycrystallinity in detrital quartz for provenance interpretation. Jour. Sedimentary Petrology, v. 45, pp. 873-882.

Basu, A. (1985) Influence of climate and relief on composition of sand release at source areas. In: G.G. Zuffa (ed.) Provenance of arenites. Reidel, Dordrecht-Boston-Lancaster, pp. 1- 18.

Bhatia, M.R. (1983) Plate tectonics and geochemical composition of sandstones. Jour. Geology, v, 91, pp. 611-627.

Bhatia, M.R. and Crook, K.A.W. (1986) Trace element characteristics of greywackes and tectonic setting discrimination of sedimentary basins. Contri. Mineralogy and Petrology, v. 92, pp.181193.

Biswas, S.K. (1992) Tertiary Stratigraphy of Kutch. Jour. Palaeontological Society of India. v. 37, pp. 129.

Biswas, S.K. and Deshpande, S. V. (1970) Geological and tectonic maps of Kutch. Bull. O.N.G.C., India, v. 7, p.115-116.

Condie, K. C., Noll, Jr. P.D. and Conway, C.M. (1992) Geochemical and detrital mode evidence for two sources of early Proterozoic sedimentary rocks from the Tonto Basin Supergroup, Central Arizona. Sedimentary Geology, v. 77, pp. 51-76.

Condie, K.C. (1993) Chemical composition and evolution of the upper continental crust: Contrasting results from surface samples and shales. Chemical Geology, v. 104, pp. 1- 37.

Condie, K.C. (1997) Plate Tectonics and Crustal Evolution. Butterworth Heinemann, Oxford, 282 p.

Condie, K.C., Lee, D. and Farmer, G.L. (2001) Tectonic setting and provenance of Neoproterozoic Uinta Mountain and Big Cottonwood Groups, Northern Utah: constraints from geochemistry, and isotopes, and detrital modes. Sedimentary Geology, v. 141-142, pp. 443-464.

Cox, R., Lowe, D.R. and Cullers, R.D. (1995) The influence of sediment recycling and basement composition on evolution of mudrock chemistry in the southwestern United States. Geochimica Cosmochimica Acta, v. 59, pp. 2919-2940.

Cullers, R.L. (2000) The geochemistry of shales, siltstones and sandstones of Pennsylvanian- Permian age, Colorado, U.S.A.: Implications for provenance and metamorphic studies. Lithos, v. 51, pp. 305-327. 
Cullers, R.L. and Podkovyrov, V.N. (2000) Geochemistry of the Mesoproterozoic Lakhanda shales in southern Yakutia, Russia: Implications for mineralogical and provenance control, and recycling. Precambrian Research, v. 104, pp. 77-93.

Dickinson, W.R. and Suczek, C.A. (1979) Plate-tectonics and sandstones composition. America Association Petroleum Geology Bulletin, v. 63, pp. 2164-2182.

Dickinson, W.R., Beard, L.S., Brakenridge, G.R., Erjavec, J.L., Ferguson, R.C., Inman, K.F., Knepp, R.A., Lindberg, F.A. and Ryberg, P.T. (1983) Provenance of north American Phanerozoic sandstones in relation to tectonic setting. Geol. Soc. American Bulletin, v. 94, pp. 222- 235.

Dickinson, W.R. (1985) Interpreting relations from detrital modes of sandstone. In: G.G. Zuffa (ed.), Provenance of Arenites. Reidel, Dordrecht-Boston-Lancaster; pp. 333- 361.

Fatima, S. and Khan, M. S. (2012) Petrographic and geochemical characteristics of Mesoproterozoic Kumbalgarh clastic rocks, NW Indian shield: implications for provenance, tectonic setting, and crustal evolution. International Geology Review, v. 54:10, pp. 1113-1144.

Folk, R. L. (1980) Petrology of Sedimentary Rocks. Hemphill, Austin, Texas, 182 p.

Fedo, C.M., Nesbitt, H.W. and Young, G.M. (1995) Unraveling the effects of potassium metasomatism in sedimentary rocks and paleosols, with implications for weathering conditions and provenance. Geology, v. 23, pp. 921-924.

Fedo, C.M., Erikson, K.A. and Krogstad, E.J. (1996) Geochemistry of shales from the Archean (3.0Ga) Buhwa Greenstone Belt Zimbabwe: Implications for provenance and source -area weathering. Geochimica Cosmochimica Acta, v. 60, pp. 1751-1763.

Gibbs, A.K., Montgomery, C.W.P., Day, P.A. and Ersley, E.A. (1986) The Archean-Proterozoic transition: evidence from the geochemistry of metasedimentary rocks of Guyana and Montana. Geochimica Cosmochimica Acta, v. 50, pp. 2125-2141.

Ingersoll, R.V. and Suczek, C.A. (1979) Petrology and provenance of Neogene sand from Nicobar and Bengal Fans, DSDP sites 211 and 218. Jour. Sedimentary Petrology, v. 49, pp. 1217 - 1218.

Lander, R. H., Bloch, S., Mehta, S., and Atkinson, C. D. (1991) Burial diagenesis of paleosols in the giant Yacheng gas field, People's Republic of China: bearing on illite reactivation pathways. Jour. Sedimentary Petrology, v. 61, pp. 256-268.

Taylor, S. R., McLennan, S.M. and McCullah, M. T. (1983) Geochemistry of loess, continental crustal composition, and crustal model ages. Geochimica Cosmochimica Acta, v. 47, pp. 1897-1905.

Taylor, S. R. and Mclennan, S. M. (1985) The Continental Crust: Its Composition and evolution. London, Blackwell, 311p.

McCann, T. (1991) Petrological and geochemical determination of provenance in the southern Welsh Basin. Geol. Soc. London, Special Publication No. 57, pp. 215-230.

McLennan, S.M., Taylor, S.R. and Kroner, A. (1983) Geochemical evolution of Archean shales from South Africa, Swaziland, and Pogola supergroups. Precambrian Research, v. 22, pp. 93-124.

McLennan, S.M., Taylor, S.R., Mcculloch, M.T. and Maynard, J.B. (1990) Geochemical and Nd-Sr isotopic composition of deep-sea turbidites: crustal evolution and plate tectonic associations. Geochimica Cosmochimica Acta, v. 54, pp. 2015-2050.

McLennan, S.M. and Taylor, S.R. (1991) Sedimentary rocks and crustal evolution, tectonic setting and secular trends. Jour. Geology, v. 99, pp. 1-21.

McLennan, S. M. (1993) Weathering and global denudation. Jour. Geology, v. 99, pp. 1-21.

McLennan, S. M., Hemming, S., McDaniel, D.K and Hanson, G.N. (1993) Geochemical approaches to sedimentation, provenance, and tectonics. Geol. Soc. America Special Paper No 284, pp. 21 40.

McLennan, S.M., Hemming, S., Taylor, S.R and Erikson, K.A. (1995) Early Proterozoic crustal evolution: geochemical and $\mathrm{Nd}-\mathrm{Pb}$ isotopic evidence from metasedimentary rocks southwestern North America. Geochimica Cosmochimica Acta, v. 59, pp. 1153-1173.

Miall, A.D. (1977) A review of the braided river depositional environment. Earth Sci. Rev., v. 13, pp. 162.

Nance, W. B., and Taylor, S.R. (1977) Rare earth element patterns and crustal evolution-II.Archean sedimentary rocks from Kalgoorlie, Australia. Geochimica et Cosmochimica Acta, v. 41, pp. 225-231.

Naqvi, S.M., Sawkar, R.H., Subba Rao, D.V., Govil, P.K. and Gnaneshwar Rao, T. (1988) Geology and geochemistry and tectonic setting of Archaean graywackes from Karnataka Nucleus, India. Precambrian Research, v. 39, pp. 193-216.

Naqvi, S.M., Subba Rao, D.V., Manikyamba, C., Nirmal Charan, Balaram, V. and Srinivasa, S. (2002) Geology and geochemistry of arenites-quartz wacke from late Archean Sandur schist belt- 
implication for provenance and accretion processes. Precambrian Research, v. 114, pp. 177197.

Nesbitt, H.W. and Young, G.M. (1982) Early Proterozoic climates and plate motion Inferred from major element chemistry of Lutites. Nature, v. 299, pp. 715-717.

Nesbitt, H.W. and Young, G.M. (1984) Prediction of some weathering trend of plutonic and volcanic rocks based on thermodynamic and kinetic consideration. Geochimica Cosmochimica Acta, v. 48, pp. 1523-1534.

Nesbitt, H., Wand, and Young, G.M. (1989) Formation and diagenesis of weathering profiles. Jour. Geology, v. 97, pp. 129-147.

Nesbitt, H.W., Fedo, C.M. and Young, G.M. (1997) Quartz and feldspar stability, steady and non-steady state weathering and petrogenesis of siliciclastic sands and muds. Jour. Geology, v. 10, pp. 173-191.

Pettijohn, F.J., Potter, P.E. and Siever, R. (1987) Sand and sandstone. Springer, 553 p.

Roser, B.P. and Korsch, R.J. (1986) Determination of tectonic setting of sandstone- mudstone suites using $\mathrm{SiO}_{2}$ content and $\mathrm{K}_{2} \mathrm{O} / \mathrm{Na}_{2} \mathrm{O}$ ratio. Jour. Geology, v. 94, pp. 635-650.

Roser, B.P. and Korsch, R.J. (1988) Provenance signatures of sandstone-mudstone suites determined using discrimination function analysis of major-element data. Chemical Geology, v. 67, pp. 119139.

Rumelhart, P.E. and Ingersoll, R. V. (1997) Provenance of the upper Miocene Modelo Formation and subsidence analysis of the Los Angeles basin, southern California: Implications for paleotectonic and paleogeographic reconstructions. GSA Bulletin, v.109 (7), pp. 885-899.

Shekhar, S., Shukla, A. and Kumar, P. (2018) Sedimentary Record of Forced Regression along the margin of Kutch basin: Terminal Cenozoic succession (Sandhan Formation), western India. Jour. Indian Association Sedimentologists, v. 35 (1), pp. 23-35.

Sreenivas, B. and Srinivasan, R. (1994) Identification of paleosols in the Precambrian metapelitic assemblages of peninsular India-A major element geochemical approach. Current Science, v. 67, pp. 89-94.

Suttner, L. J. and Dutta, P.K. (1986) Alluvial sandstones composition and paleoclimate, I, framework mineralogy. Jour. Sedimentary Petrology, v. 56, pp. 329-345.

Webb, G. E. (1994) Paleokarst, paleosol, and rocky-shore deposits at the Mississippian-Pennsylvanian unconformity, northwestern Arkansas. Geol. Soc. America Bulletin, v.106, pp. 634-648.

Wright, V. P. (1994) Paleosols in shallow marine carbonate sequences. Earth-Science Reviews, v. 35, pp. 367-395.

Weltje, G.J., Meijer, X.D. and P.L. de Boer (1998) Stratigraphic inversion of siliciclastic basin fill: a note on the distinction between supply signals resulting from tectonic and climatic forcing. Basin Research, v. $10(1$,$) pp. 129-153$.

Wildeman, T.R. and Condie, K.C. (1973) Rare earths in Archean greywackes from Wyoming and from the Fig Tree Group South Africa. Geochimica Cosmochimica Acta, v. 37, pp. 439-453.

Wronkiewicz, D.J. and Condie, K.C. (1987) Geochemistry of Archean shales from the Witwatersrand Supergroup, South Africa: 421. Source area weathering and provenance. Geochimica et Cosmochimica Acta, v. 51, pp. 2401-2416.

Wronkiewicz, D.J. and Condie, K.C. (1990) Geochemistry and mineralogy of sediments from the Ventersdorp and Transvaal Supergroups, South Africa: Cratonic evolution during the early Proterozoic. Geochimica Cosmochimica Acta, v. 54, pp. 343-354.

Zimmermann, U. and Bahlburg, H. (2003) Provenance analysis and tectonic setting of the Ordovician clastic deposits in the southern Puna Basin, NW Argentina. Sedimentology, v. 50, pp. 1079 1104. 